\title{
電気・電子材料としての高分子の諸問題
}

\author{
桜 内 雄 二 郎*
}

\section{1. 電気電子工学とプラスチックス}

最近の電気工学電子工学の進歩は実にめざましいるの がある。たと觉ば增幅素子では真空管からトランジスタ へ, さらに薄膜能動素子へと進歩し, 回路部品は微小化 の方向に進文軽量でしかる確実に動作する誘導装置の開 発により，ミサイルの開発，人工衛星の開発にいたるま で発展するようになった。

このような霞気・震子技術の発展は，もらろん各種材 料工学の進歩の裏づげよってはじめて完遂されたもの であるが，高分子材料の進歩に負うところがきわめて大 きい。戦前ではプラスチック材料とい衤ばセルロイドと ベークライト以外には見るべきものがなにるなかった が，その後発展したプラスチック技術は多種多様のプラ スチックを創造し，その性質も，吹質製品，硬質の材 料, 耐電压の強いるのから高周没特性のすぐれたもの, きわわて機械強度の強い材料など, 機械材料, 磁器材料 にはみられない上うな特殊な性質をもつ材料がつくられ るようになっでっこれらのすぐれた特性をるつプラスチ ック材料は，電子工学のあらゆる分野に進出し盛んに実 用され，その実用領域を広大しつつあるが，さらに電 気，電子技術の進歩に伴なって，よりすぐれた特性をる つプラスチック材料が要求されるようになってくる。本 項では，このような電気，電子技術に使われている高分 子材料の現状の概要とその䦗題点について述べてみるこ とにする。

\section{2. 高分子材料の電気, 電子工学への応用}

プラスチック材料は，電気工学，電子工学のあらゆる 分野に進出し，実用されているが，その使用状態は第 1 表特よび第 2 表に示すようなるのである。本表について わかるようにプラスチック材料の主な用途は絶緑材料で あるが，その他にる，種々の特殊な応用がプラスチック 材料の持ら味を生かして行なわれている。

\section{2-1. 絶緑材料としての応用1}

*Yujiro SAKURAUCHI 日本放送協会技術研究所・工博 Severe1 Problems of High Polymer for the Electronic and Electrical Engineering Materials
第 1 表の項目に分類した，(1)積層板，(2)成形物，(3)ヶ ーブル，コード類，(4)テープシート類がこの中に含まれ る。

絶縁材料は低周波用絶縁材料と高問波用絶縁材料との 2 種に大別される。

プラスチック材料は概して良好な絶緑物で，低周波用 絶縁材料としての特性上の問題は㟧せりないが，プラス チック本来の特性, すなわら, 耐熱性, 機械強度などの 特性と，価格がより大きな要素になってくる。したがっ て，低周波絶緑材料としては，特性上あ⿱亠問題になる 点は，見当らないと考学てよいのではないだろうか。

しかし，高周波絶縁材料の分野では，その要求が緻密 になり，複雑多岐にわたる特性が要求される。

いせプラステック絶縁材料を第 1 図aのような平行

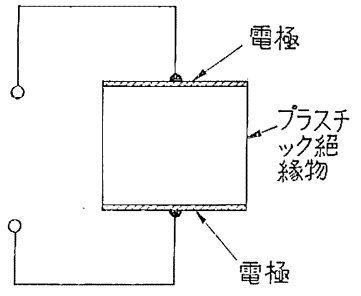

(a)



(b)
第 1 図

板電極の中に㧴入した場合を考学ると，この状態に和け る等価回路は，第 1 図bのように抵抗と容量の並列回路 で示される。この回路の実効インピーダンス $|z|$ 和よび 回路の消費エネルギー $w$ 注次のような関係で示される。

$$
\begin{aligned}
& |z|=\frac{1}{2 \pi} \cdot \frac{1}{\sqrt{1+\tan ^{2} \delta}} \cdot \frac{1}{f} \frac{1}{\varepsilon C_{0}} \\
& W=0.556 f \varepsilon \tan \delta V^{2} \times 10^{-12}\left[\mathrm{~W} / \mathrm{cm}^{2}\right]
\end{aligned}
$$

ここに, $f$ は周波数 $\mathrm{cps}, \varepsilon$ 注誘電率， $C_{0}$ は電極間の 幾何学的容量（電極閒に誘電体をはさまない真空状態に

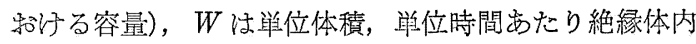
に消費されるェネルギー, $V$ 性印加䨖場の強さ $\mathrm{V} / \mathrm{cm}$ を示す。高周波絶縁材料としては $Z$ の值をなるべく高 くとり，Wの值を小に選ばなくてはならない。この傾 向愉波数 $f$ の值が大になるにつれて要求が増してく る。 $Z$ の值を小にするるためには $\varepsilon$ の值が小さいことが 
第 1 表高分子材料のエレクトロニクス虑用

\begin{tabular}{|c|c|c|c|}
\hline No. & 項 & 応 & 使用されている樹脂 \\
\hline 1 & 䅡 層 板 & $\begin{array}{l}\text { 絶緣板, プリント基板，ソケット， } \\
\text { 小物部品 }\end{array}$ & $\begin{array}{l}\text { フェノール, 手シレン, エポキシ， ジア } \\
\text { リルフタレート，ポリエステル，シリコ } \\
\text { ン, フラン }\end{array}$ \\
\hline 2 & 成 形 物 & $\begin{array}{l}\text { ソクット, プラグ, 電子装㯰, 小物部品, } \\
\text { 箱 }\end{array}$ & $\begin{array}{l}\text { フェノール, エポキシ, 尿素, ポリエス } \\
\text { テル }\end{array}$ \\
\hline 3 & ケーブル・コード類 & TVコード, フィーダー, 電源コード & $\begin{array}{l}\text { ポリエチレン, 合成ゴム 塩化ビニル, } \\
\text { ポリスチレン, ポリプロピレン, シリコン }\end{array}$ \\
\hline 4 & テープシート類 & 絶縁テープ & 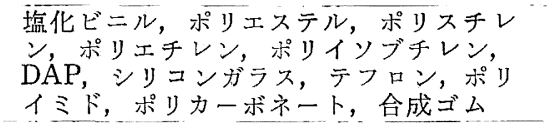 \\
\hline 5 & 接 着 剂 & & $\begin{array}{l}\text { エポキシ, フェノール, 塩化ビニル, } \\
\text { その他 }\end{array}$ \\
\hline 6 & 絶 縁 塗 料 & & $\begin{array}{l}\text { エポキシ, フェノール, 壦化ビニル, } \\
\text { ポリウレタン, アクリル樹脂 }\end{array}$ \\
\hline 7 & 回 路 応 用 & & $\begin{array}{l}\text { 䀄電性プラスチックス, 抵抗性プラスチ } \\
\text { ックス, プリント基板 }\end{array}$ \\
\hline 8 & ，回 路 部 品 & 抵执，コンデンサ類 & $\begin{array}{l}\text { ポリェステル, ポリスチレン, ポリエチ } \\
\text { レン, テフロン, ポリカーボネート, } \\
\text { ェノール, エポキシ }\end{array}$ \\
\hline 9 & 音 響 材 粦 & $\begin{array}{l}\text { 録音テープ, ダムパー，ビニル点板 } \\
\text { 吸音材料，遮音材料，録音船 }\end{array}$ &  \\
\hline 10 & 録画，録音，テープ & $\begin{array}{l}\text { TPR 録画テープ(熱可塑性樹脂フィルム } \\
\text { 錄画) } \\
\text { V }\end{array}$ & 湓化ビニルフィルム \\
\hline & & VTR 録画(磁気テープ録画) & ポリエステルフィルム（マイ \\
\hline 11 & 映画フィルム & テレビ用映画フィルム & $\begin{array}{l}\text { 三酢酸綿フィルム, } \\
\text { ポリエスフィルム }\end{array}$ \\
\hline 12 & 電 波 無 響 室 & 発 泡 材 料 & 発泡ポリスチレン \\
\hline 13 & $\begin{array}{l}\text { 㐘車, 䡍受け, } \\
\text { 機構部品 }\end{array}$ & $\begin{array}{l}\text { 無音㮃受け, 歯車, 機模部品 } \\
\text { モーター絶緑物 }\end{array}$ & $\begin{array}{l}\text { フェノール観層品, ナイロン, ポリアセ } \\
\text { タール(デルリン), ポリカーボネート, } \\
\text { ポリプロピレン }\end{array}$ \\
\hline 14 & 光 学 応 用 & $\begin{array}{l}\text { シュミットレンズ, コンタクトレンズ } \\
\text { 偏光板, フィルタ }\end{array}$ & $\begin{array}{l}\text { メタクリルサンメチルサクサン綿 } \\
\text { 耐熱性メタクリル酸樹脂 }\end{array}$ \\
\hline 15 & 受 像 管 製 作 & $\begin{array}{l}\text { メタルバック用ラッカー } \\
\text { 感光性樹脂 }\end{array}$ & $\begin{array}{l}\text { 硝化綿, メタクリル酸およびアクリル酸 } \\
\text { エステル } \\
\text { ポリビニルシンナメート(KPR), ポリビ } \\
\text { ニルアルコール }\end{array}$ \\
\hline
\end{tabular}

必要で, $W$ の值を極力小さくするためには， $\varepsilon \tan \delta$ の 值を小さくすることが必要となる。

すなわち, $z$ の値が大であると, 高周波的に絶縁材料 㕫なくなり，ぬた $W$ の值が大であると，高周波エネ ルギーを消費し，また絶緑材料が発熱し烧損してしまう


値が極力小なることが要求され，秃た，耐熱性の䯩いこ とが要求される。

もらろん, ここに述べた $\varepsilon, \tan \delta$ の值も使用周波数 によって, 要求される值は異なるもので, 比較的低い祘 波数では $\varepsilon, \tan \delta$ の値はある程度許容されることにな る。

現在, 使用されている高周波紿縁材料に祸いては, 伎
用場所によって設訃值の変わることもあり，周波数に対 しての, $\varepsilon, \tan \delta$ の值の許容度の区分ははっきり定め られないが，その概算值は次のような值に落らつくもの と思われる。

$0 \sim 10^{6} \mathrm{cps}(1 \mathrm{Mc}) \cdots \cdots \cdot \varepsilon$ の俻 6 以下, $\tan \delta 10^{-1}$ 以下

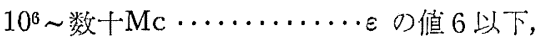

$\tan \delta 10^{-2}$ 以下

数十 $\mathrm{Mc} \sim$ 数百 $\mathrm{Mc} \cdots \cdots \cdots \cdot \mathrm{*}$ の值 2.5 以下, $\tan \delta 10^{-3}$ 以下

数百 $\mathrm{Mc}$ 以上 $\cdots \cdots \cdots \cdots \cdot \cdots$ の值 2 以下,

$\tan \delta 10^{-4}$ 以下

したがって，数十 Mc 以下の周波数ではベークライト

Vol. 13, No. 151 
積層㤆,キシレン積層板，エポキシ積層板などが使われ， $100 \mathrm{Mc}$ 以下の閒波数では積層㤆が使用される場合でも， 霍極間間隙を広くとるなどの注意を払わねばならない。

この周波数ではポリエチレン，ポリスチレンなどの材 料恋でが俌用できることになる。

さらに，消い周波数になり，数百 $\mathrm{Mc}$ 带に及ぶと，現 在, 一般に契用されてい方絶縁物中, 最高級のテフロン 以外には使えなくなる。

\section{2-2. 接着刜, 塗料}

機棈材料としての接着剤は，電気応用の分野でも，普 通使われている市肘按着剤, たと党ばエポキシ系接着

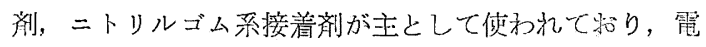
気用専門としてつくられた特列なるのはない。

電子工学用の特殊接着郕として処法されたるのに尊電

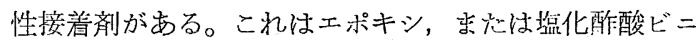
ル樹脂のなかに導電性の良い金属粉末，たと完ば銀粉を 混合して導電性を与皇たるので，電子部品の接緢部に低 温導電接続をするために使用されている。

整料関係に和好る電子工学技術の汒用は機構応用につ いては接着剤の場合と同様に，防サビ染料として一般用 の塗料が使われているが，電気電子工学用の特殊心用之 して絶緑塗料が使われる。緮䋎叙料としてはエポキシ樹 脂, フェノール樹脂, キシレン樹脂, シリコンワニスな どが使われ，電線用エナメル塗料としてはポリビニルホ ルマール，ポリウレタン，ナイロン塗料が使われてい

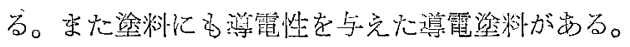

\section{2-3. 回路応用, 回路部品, 普響材料}

回路応用としては，積畨板に銅澁をはりつけたプリン 卜基板があるがこれ以外に，自放車の点火栓の笔気回路 に使って障素波の防止をはかる炭素含有プラスチック坻 抗ひもでつくられたノイズサプレッサーコードがある。 これはをだわが国では試作品程度のものがつくられてい るだけである。この他に，プラスチック㕨に極微細な銀 粒子を分散させた尊電性プラスチックがある。

回路部品へのプラスチック応用は雷要なエレクトロニ クス技術の翼瑟の一つになっている。回路部品応用の5 ら，プラスチック材料が最も多く使用されているるの汪 容量素子である2゙。誘電体材料として, ポリエチレン, ポリスチレン, ポリプロピレン, テフロン, ポリカーボ ネート，ポリエステルフィルムなどそ使われている プラスチックフィルムの種類尚非常に多い。このよ5な プラスチックフィルムが各从特徽裳生かされて使われて いるのでかる。

回路部品に使われているプラスチックス材料で容量素 子応用以外に注抵抗素子の成形用として, フェノール樹 脂，エポキシ樹脂が炭素結合用として使用されている。 この結合斉は, モールド抵抗, 可変抵抗の製作上, 重要 な位置を占るている。
プラスチック材料の音響応用としては, 重要な分野が 3 種山る。そ第 1 は音響機器のダンパーで, 機器の共 振を防止し，音質を改善するた脄使用するもので，合 成ゴムダンパー，シリコン油父パーなどが用いられて いる。

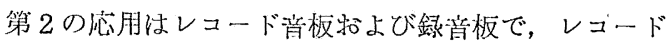
皅㤆としては塩化ビニル，酶酸ビニル共重合樹脂が使わ れ，録音盤材料としては硝化綿が主材料として使用され ている。

いま一つの応用は吸音忉料特よび遮音材料応用で，ポ リウレタン，ポリ塩化ビニル，永素樹脂特よびフェノ一 ル樹脂の多孔体が吸音材料として使われ，なた，鉛粉末 を充てんしたビニル樹脂シートが遮音板材料として使わ れている。

\section{2-4. フィルム, テーフフ頪 ${ }^{3 !}$}

電気工学, 電子工学に佑われている絶緣テープとして は塩化ビニルテープをはじめとして央用されているフィ ルム,テープ類はきわめて多い。酎熱絶縁デープとして はシリコン一ガラスクロステープ・テフロンデープが あり，高周波用絶縁テープとして，ポリエチレンフィル ム，ポリスチレンフィルムなどがあり，矢の他マイラー テープ, ポリカーボネートなどが実用され，今後实用化 が進められるるのと思われるテープフィルムとして，耐 熱性ポリイミド系Hフィルム， 世ミキュアー樹脂フィル ムDAP フィルムがあり，新製品が続及登場しつつある 現状である。

近年，新しい録画方式としてつくられた磁気録西（V TR）では，磁器ヘッドが回転し，ぬれ，磁気へッドと 錄音テープの間にかかる圧力は数トンもの值に進する。 このようなきびしい条件に耐觉るフィルムとしては，見 在のところポリエステルフィルム, マイラーフィルム以 外にはない。

音声記録用，磁䜪録音テープとしては，磁氛録画用テ ープのようなはげしい使い方は要求されないため，二䤀 隌綿デープが使われる。

$\mathrm{TV}$ 用 $16 \mathrm{~mm}$ 佒画フィルムとしては三眽化綿フィル ムが使われている。硬質で，耐熱性があり，耐湿性の強 い点が利用されたものである。

\section{2-5. その他の応用}

電洨然響室の発泡材料にはポリスチレン多孔体が使わ れている。

スタジオ内装置には無音であることが必要で，機棰部 品として，ポリアせタール，ポリカーボネート，ポリプ ロピレン, ナイロン,フェノールなどの樹脂の崡車, 軸 受けなどの機構部昆が使われている。

放送技術で使われているプラスチック材料の光学応用 はシュミットレンズ・カラーフィルタ拉よび偏光フィル タである。シュミットレンズは投射型ブラウン管の映像 
をスクリーン上に投影するときの光学レンズ，カラー・ フィルタは天然色 $\mathrm{T} \mathrm{V}$ 技術の送像側, 受像側の色分解, ぬたは色合成に使われる。

TV 受像管の子い光体暁着には高分子感光材料が使わ れる。滈分子感光材料としては，ポリビニルシンナメー 卜，卵白一一重クロム酸系感光材料である。

汀い光面に金属定蒸着さ㕹万メタルバックの前処理と して，プラスチック塗料を吹きつけるラッカリング工积 があるが，この工程に使用するプラスチック塗料とし て, 硝化綿塗料, メタクリル酸特よびアリリル酸エステ ルが用いられている。

\section{3. プラステッック材料とその問題点}

電效，電子工学に使われるプラスチッ材料でも，そ の欠点 (Neckpoint) としては機械材料，日用品など一 般用途に使用する場合の欠点と共通な弱点が，最る大き な特性上の問題点であることで第る。すなわる，まず第 1 にブラスチック材料の機械特性, 強度法温虔依存性が きわめて高いが，電気特性の温度低存性も同じ傾向をも っている。たと祝, マイラーフィルムコンデンサにつ いて例をとると，第 2 図に示すように，容量值が $100^{\circ} \mathrm{C}$



(a)

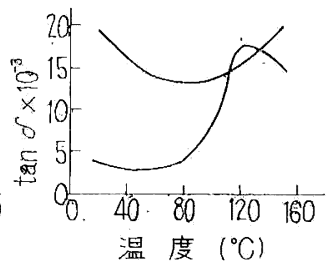

(b)
第2図 マィラーフィルムコンデンサの容量および $\tan \delta$ の温度特性 2

以上で急激に增加し $140{ }^{\circ} \mathrm{C}$ 以上で $17 \%$ 以上る增加す る。 $\tan \delta$ の值る同様に变化がはげしい。この傾向はテフ ロンコンデンサのよらな比較的努定なプラスチック材料 でつくられたと思われるコンデンサでる全く同様と容量 值䄈よび $\tan \delta$ の值の温度依存性はかなり高い(第3図)。 つ亭り，プラスチック材料の泣き所は特性の温度依存性 である2。

低周波用絶縁材料としては機械特性強く，絶縁性の

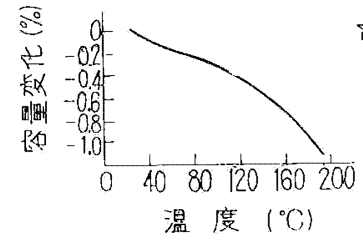

(a)



(b)
第3图 テフロンフィルムコンデンサの容量および $\tan \delta$ の温度特唑 ${ }^{2}$
きわめて良いプラスチック材料があり，積層板として強 化プラスチックにもできるので, 現在の技術水準では十 分実用できる材料がそるっているので問題は，価格の点 だけにしぼられる。すなわ方，絶緑性の良い材料はいく らでも京るが, 電気業界では, 岀くて, 機械的に強い材 料が要望されるようになった。

高周波用絶縁材料, 特に数百 Mc 以上の周波数带に使 埥るプラスチック材料には使用できる種類が限定され る。つ京り, ポリチレン, ポリスチレン, テフロンな どの材料に限定され, また充てん枌为自由に選定し, 混 人，積尿乙て機械特性を改善することはむずかしい。近 年, ポリプロピレンのような強力な樹脂ができるように

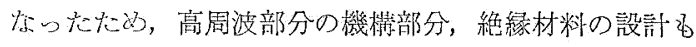
だいぶ見通しが明るくなっている。

プラスチック材料妾取り报う場合には常に熱の問題が つききとってくる。積愿板, 特にプリント基板ではハン ダ浸積工程で曲がりが発生する。この彎朋はプリント基 板製作上，非常に大きな䦗題で，しかるフェノール樹脂 基板程度の峃仙な材料でつくられなければならないとこ ろに技術的な困難な問題が横たわっている。

電子工学用コンデンサ材料, 誘電体フィルム材料とし ては高誘電率，低 $\tan \delta$ 特性のものが望尔しい。現在， 誘䉓率が 12 19 程度の子のはシアン化セルロース樹脂 で実現されているが4)，磁器材料のようにさらに高い誘 電率数百から数千革でのフィルムが実用化されるならば 電子工学用としてきわめて有用な材料瓜るだろう。る ちらんこの場合に叔いて, 低 $\tan \delta$ の条件が満足さ れ，湿度に影響されれなるのでなければならない。

高周波絶緣材料としては，これとは全く逆に，低誘電 率, 低 $\tan \delta$ の特性のるのが強く要望されている。誘電 率が 1 にきわ近い值のものは発沦ポリスチレン, 発 泡ポリエチレンで実現されているが，材質が部分的に均 一でなく，機械強度が弱いために特定な䇫所以外には使 用に耐觉ない。均一な材質で，機械強度が十分にあり， 低誘電漂，低 $\tan \delta$ 材料ができ得れば電子技術材料とし てきわめてすぐれたものとなるだろら。

VTR（磁気録画）技術では録画テープに数 $t / \mathrm{cm}^{2}$ の 玨力が印加され，乙か子，録音へッドは，高速に回転し ているから現在使用されているポリエステルフィルムで る雨生回数は 200 回程度であるという。さらに強くて薄 いフィルムの出現が望京れる。

次に，音響材料に視界を忶じてみよ5。吸音材料とし ては建築材料としての要素を多分にもっている。したが って色彩感覚も美しく，清潔な感じのプラスチックフォ 一ム理想的な建築吸音材料として認められる。それ にるかかわらずあをり使用されて䄱らないのは価格の間 題だけで“使用できない技衍上の理由全く見当らな い”。安くて，美しいプラスチック吸音材料の出現が望 
まれる。

電子工学には真空はつきるのである。一般のプラスチ ック材料では高真空中に挿入すると, 樹脂中からガスが 放出され真空度を著しく害する。現在, 真空用グリース にはシリコングリースが用いられ，沓た真空用エポキシ 樹脂では 10-8 $\mathrm{mmHg}$ 束で保持できるといわれている が5)，大きな情造体をプラスチックで成形し，真空保持で きるような安価な材料ができれば，防爆禪造安全ガラス でっくられたTV 受像管る萝ではなくなるはずである。

電気, 電子技術に使用されるプラスチック材料の上述 以外の問題点を簡戦に述べてみよう。

宇宙通信の衛星打ち上げ用ロケット材料には耐熱, 柽 量構造のプラスチック材料が要求される。

プラスチック絶緑材料では表面に静電気を帯電するこ とがある。これを防止するために带電防止処理を行なう が，現在，界面活性剤を使う方法，オルガノシリケート を使用する方法があるが，これでもな搞不十分な場合が ある。さらに強力な帯電防止剤がでされば便利である。

現在ある導電性樹脂材料は導電性を与兄るために銀粉 を使うか，炭素粉を混和しているが炭素粉を使用したも のは導電性が良くない。禿た銀粉を使ったるのは高価で ある。導電性が良くて安価な材料が望まれる。

感光性樹脂では，光の波長，または電子線の波長によ って感光度の異なる感光性樹脂が望まれる。

スクリーン・プロセス用のスクリーンを製作する場 合, ツギ目なしの, 折り目なしの $3 \mathrm{~m} \times 4 \mathrm{~m}$ 程度のプラ スチッククロス，またはシートが要求される。簡単な方 法でつくりらるならば，安いプロセス用スクリーンを試 作することができるであうう。

\section{4. 結言}

電子技術もプラスチック技術るきわひ進歩の早い科 学である。電気，電子技術が発展すれば，それに使用さ れるプラスチック材料もさらにすぐれた忉料が要求され ることは当然である。

電気電子材料として見た場合に要求されるプラスチッ ク材料の特徴を述べてみよう。

（1）電気，電子技術からのプラスチック材料への要 求はさわわて, キメが細かい。たと党ばテフロン樹 脂の誘電率は 2.0 であるが，これが 0.5 だけ下げた 1.5 程度になると大さな問題になる。このようなこ

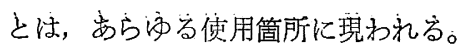

（2）電気電子工学材料, 特電子工学材料注, 使用 量が少ないにかかわらず，特性は高度のものが要求 される。従来は他の目的につくられた樹脂材料を導 入乙て使っていたが, 現在では電気, 電子材料とし ての目的でつくられたるのる多く出回わるようにな った。

（3）電気電子材料としてのプラスチック材料の性能 上の要求はきわめて多岐にわたって物り, 現在つく られているプラスチック材料の汪とんどずててにわ たって使用され，さらに非常に特殊なプラスチック 材料末で要求されている。

(4) 電気, 電子工業も他の工業と同様に競争がはげ しく, 安価なしかる特性の良い材料が要求される。

プラスチック工業も見在，一つの大きな転機にさしか かっているのではなからうか。ストレートな構造をるつ 高分子は大体出そろった形で, 今後 Polyalloy 時代に 移って行くのではないだろうか。京た，無機元素，金属 元索をその主憡造のなかに含めた新しい, Organo metaric polymer, ※をは Inorganic-organic co-polymer などの出現が期待されるのではなかららか。

少し夢物語に近くなるが, 驚異的なプラスチック材料 技術の進歩を考光るならば，萻電性透明プラスチックの 出現も可能ではないだろうか。李たプラスチック半導 体を使つたトランジスタはできないるのだらうか。

電子工学の進歩を考党, プラスチック技術の然限の可 能性を信じるならば，厹う遠くない将来，この夢物語も みごとに実現される日も，必ず来るように思われる。

\section{文献}

1) 兴内雄二郎：電気電子技術者のためのプラスチッ ク材料の選び方, 使い方, 98, 日刊工業新聞社

2) J. H. Cozen: "Development of Plastic Dielectric Capacitors"; IRE, Transaction on Component Part (June 1959)

3) 文献 1)の 136 ページ

4) "New Cyanocell Highest Dielectric Constant, Extra Row Dissipation factor", American Cyanamid. Co.

5) Torr Seal: "Low Vapor Pressure Resin Data and Instrument Sheet Model", No. 593,0001; Varian Associated. 